Walisongo: Jurnal Penelitian Sosial Keagamaan

Vol. 28 No. 1 (2020) pp. 1-28

DOI: $10.21580 /$ ws.28.1.6294

\title{
A Soft Approach to Counter Radicalism: The Role of Traditional Islamic Education
}

\author{
Syamsul Ma'arif, ${ }^{1 *}$ Leonard C. Sebastian, ${ }^{2}$ Sholihan Sholihan ${ }^{3}$ \\ ${ }^{1,3}$ Universitas Islam Negeri Walisongo, Semarang, Indonesia; ${ }^{2}$ S. Rajaratnam School of \\ International Studies (RSIS), Singapore
}

\begin{abstract}
This study sheds light on the identity of Islamic education in Indonesia and Singapore to fight against radicalism. This study focuses on comparing Indonesia and Singapore in awakening multicultural consciousness, particularly on philosophical and practical religious education. The crisis of ideology faced by Muslim society in the world has an impact on the genesis of religious movements that legitimate violence and terrorism. This study is based on the sociological perspective and aimed at knowing the philosophical and practical construction of Islamic education in Indonesia and Singapore. The focus of this study is on preventive and persuasive deradicalization. Religious education institutions in both countries have multi principles and practices of education, which is implemented particularly in preventing Islamic ideology that teaches violent values and terrorism. Anticipating the development of understanding radicalism, in both countries, Islamic education has formulated policies that are accommodating with universal values and cosmopolitanism of Islamic civilization. Such efforts are implemented by pesantren and madrasah in Indonesia and Singapore to build harmony among fellow human beings and transmit the character of egalitarian, democratic, humanist, inclusive, and civilized.
\end{abstract}

Kajian ini menawarkan perspektif baru tentang peran pendidikan Islam di Indonesia dan Singapura untuk melawan radikalisme. Fokus kajian ini adalah membandingkan Indonesia dan Singapura dalam

*Corresponding Author: Syamsul Ma'arif (syamsul_maarif@walisongo.ac.id), Universitas Islam Negeri Walisongo, Jl. Walisongo No. 3-5 Semarang, Indonesia 50185.

ISSN 0852-7172 (p) 2461-064X (e)

(C) 2020 by Authors, published by Walisongo: Jurnal Penelitian Sosial Keagamaan https://journal.walisongo.ac.id/index.php/walisongo 
usaha membangkitkan kesadaran multikultural, khususnya pendidikan agama yang bersifat filosofis dan praktis. Krisis ideologi yang dihadapi masyarakat muslim di dua negara ini berdampak pada labirnya gerakan keagamaan yang melegitimasi kekerasan dan terorisme. Kajian ini didasarkan pada perspektif sosiologis dan bertujuan untuk mengetahui konstruksi filosofis dan praktis pendidikan Islam di Indonesia dan Singapura. Fokus kajian ini adalah pada usaha deradikalisasi secara preventif dan persuasif. Lembaga pendidikan agama di kedua negara memiliki multi prinsip dan praktik pendidikan yang diimplementasikan khususnya dalam pencegahan ideologi Islam yang mengajarkan nilai-nilai kekerasan dan terorisme. Mengantisipasi perkembangan paham radikalisme, kedua negara merumuskan pendidikan Islam yang akomodatif dengan nilai-nilai universal dan kosmopolitanisme peradaban Islam. Upaya tersebut dilakukan oleh pesantren dan madrasab di Indonesia dan Singapura untuk membangun kerukunan antar sesama manusia dan menyebarkan karakter egaliter, demokratis, humanis, inklusif, dan beradab.

Keywords: cosmopolitanism; counter-radicalism; Islamic education

\section{Introduction}

Violence is always related to an event that is horrid, frightening, painful, and dreadful. It always happens in all aspects of human life, such as religion, social, politics, economy, culture, and education. Moreover, it happens in a fundamental aspect of belief, namely, religion. The phenomenon of violence seems to have copyright and confirm itself to grow and live together with human beings. One type of violence is called religious violence. Religion is given and teaches about love and peace for humans, but nowadays, it becomes a "fertile field" of religious practices that legitimate intolerance and violence.

According to Rijal (2010), radicalism is a product of the $20^{\text {th }}$ century in the Moslem world, particularly in the Middle East. The radicalism is a product of the identity crisis faced by Moslem that triggers a resistant behavior to the West countries. Moreover, Dekmejian, as quoted by Rijal (2010), mentioned that the separation of the Moslem world into some nation-states and the project of modernism proclaimed by West adherent government has an impact on the weakness of religious and moral bond 
among Muslims. Because of the reasons, the emergence of a resistant behavior to the West and movements of purification of Islam is assumed as the solution. This movement also resists the regime of government that is claimed to deviate from religion and tends to be secular.

There are some terms used to define intolerant movements and the movements that legitimate practices of violence in its teaching, namely fundamentalism, revivalism, activism, and extremism. However, in this paper, radicalism is chosen as the identity of such a radical movement group. Islamic radicals or Islamic radicalism, as explained by Jahroni (2004, pp. 2-3), refers to a group that has strict belief to a certain ideology and has a fanatism attitude. They use their fanatism to struggle to change the values and system that is going on. In practice, this group focuses on an attempt to evaluate, refuse, and resist the social life order that they think it deviates. Accordingly, to change the system, which is in progress, they administer programs of an ideological process to substitute the system that will be changed.

The study about religious education on contra-radicalism is chosen in this study, trace belief and ideological process conducted by radical Islamic movements with religious education as the instrument to resist the radicalism. The study relating to contra-radicalism education was conducted by Machali (2013, p. 41) through the concept of peace education. The concept reveals that education can develop behavior and attitude to respect each other, become tolerant, peaceful, helpful, and antiviolent. Misrawi (2013, p. 197) synthesized that the wave of radicalism can be blocked by multicultural consciousness derived from the values of Bhineka Tunggal Ika. Fantastically, our nation philosophy is too perfect in giving the understanding to establish a tolerant and friendly society toward others. Besides, Arifin (2014, p. 409), in his study, argues that multicultural education becomes the ultimate device in the process of deradicalization.

Another study that is relevant to this discussion regarding contraradicalism education was conducted by Ma'arif (2016). In his study, it 
was found a concept of Islamic Education Curriculum based on Multiculturalism as a solution to Islam, which stresses tolerant teachings. At the same time, Hilmy emphasized the process of deradicalization conducted through the guidance of human rights that belong to the Islamic radical group (Hilmy, 2013, p. 130). The guidance as an effort to proceed deradicalization is also explained by Umam (2006, p. 1). He asserts that formal education is not enough; the deradicalization needs preventive attempts by instructing youth to avoid extremism and terrorism groups.

From the previous study, it can be concluded that the prior studies were still concerned about the identity of Islamic Education implemented in religious education institutions such as pesantren or madrasah. Thus, this study completes the prior studies by proposing three research questions as follows: 1) what are the bases and principles of Islamic Education in Islamic education institution in Indonesia and Singapore. 2) how are practices of Islamic education in both countries in attempting to deradicalization. It is important to prepare a role model of educational institution that teaches tolerance and peace of Islam. This study is expected to become a reference for the international world in implementing an ideal religious education. The analysis of the identity of Islamic education determines the polarization and character of teaching and nurture, especially relating to an effort to resist religious radicalism. In this study, the sociological perspective is used to discover the typology and formula of religious education developed by Indonesia and Singapore.

Then, the analysis was used to sheds light on the concept and practice of Islamic Education, which contains contra-radicalism teaching both in Indonesia and Singapore. Moreover, this study is aimed at attempting to give understanding to society about tolerant and inclusive Islamic education. In this sense, religious education does not legitimate the praxis of violence in the teaching-learning process. It is critical to say that through religious education, peacefulness can be reached-of course, religious education is tolerant and humanitarian education. 


\section{Radical Islam in the Globalization Era}

The term "radicalism," which is related to fundamentalism, was explained by Esposito (as quoted by Rijal, 2010, p. 216) by associating it into three cases. First, those who proclaim to revert to the most basic religious teaching. This group can be called a fundamentalist group. Secondly, the understanding and perception of fundamentalism are influenced by the American Protestant group, namely a protestant movement in the 20th century. This group interprets the Bible literally. The reason is that literal interpretation becomes a fundamental matter for Christian's life and teaching; thirdly, the term "fundamentalism" is often called as political activism, extremism, terrorism, and anti-American.

Accordingly, Esposito assumes that the term "radicalism" tends to Christian presupposition and West stereotype and signify a monolithic threat. Thus, he prefers to use the term 'revivalism Islam' or activism Islam,' according to him, the terms are balance and have roots in Islamic tradition. Besides, he argues that "Islam has long tradition begins from awakening (tajdid) and reformation (islah) that include an idea about social and political activism begins from early Islam until Islam at present" (Esposito, 1995, pp. 8-9).

Umam (2006, p. 172) tries to elaborate the thought of Bruinessen, Mujani, and Huntington in responding to the genealogical roots of the radical Islam movement. One of the ultimate backgrounds of the emergence of the radical Islam movement is the historical heritage of conflict among Muslims caused by political oppression from the state (Umam, 2006, p. 172). In line with Umam, Bakri (2004, p. 6) asserts that socio-political symptom becomes the basis of violence in regard to religion. In the global context, Azra (2002, p. 18) describes that the worsening position of Muslim States in the North-South conflict becomes the main support of the emergence of radicalism. Historically, we can observe that conflicts made by radical groups by implementing violence and ramming themselves to another group are rooted in socio-political problems. 
Also, according to Bakri (2004, p. 6) rationale of radicalism was born and develop due to the religious emotion, cultural factor, and factor of anti-western ideology. Some factors emerge because of an understanding that the West is accused as the cause of the decline of Muslims with their political strategy and secular culture brought by them. Besides, there are also phenomena of economy-politics; there are oppressions on economypolitics. Another argumentation reveals that radicalism emerges due to the excess of capitalism. As a consequence, those who don't have a source of capital will be eliminated. In the term of economy-politics, this approach is called "class approach." Meaning that response of radicalism is the response of class to resist the hegemony of capitalism and oligarchic government. In this context, the hegemony of capitalism refers to the hegemony of West capitalism that causes Islam to become the oppressed community and occupy the object in the locus of the economic world.

\section{Identity of religious education in realizing deradicalization}

Education becomes an effective instrument in the practice of blocking the current religious radicalism. Another study conducted by Rokhmad (2012, p. 79) that is more concerned with implementing Islamic education. The implementation of religious education should run through a strategy of preventive deradicalization, preservative deradicalization of moderate Islam, and curative deradicalization. Religious education is the most appropriate solution in the process of deradicalization, for instance, the teaching-learning process in pesantren.

Ma'arif (2016) criticizes national education that is far from ideal. The education keeps producing humans that are far from the vision of deity and humanity. Their behaviors and attitudes depict the society that spread out violence and hatred to others. It is not surprising. Our education can be colonialized easily by the Islamic ideology that uses violence in their teaching (Ma'arif, 2016, p. 1). In line with Ma'arif's synthesis, Noor et al. (2008) formulate a typology of pesantren, namely, traditionalist pesantren and Islamist pesantren. In fact, Islamist pesantren becomes process 
ideology of the radical Islam Movement; however, substantial and essential Islamic teaching is taught in traditional pesantren.

The writer argues that religious education becomes the most effective model as a contra-radicalism movement. In Indonesia, we know pesantren, and it is not too different. Singapore has a proper model of religious education. Kosim (2011, p. 441) asserts that religious education, which develops in Singapore, is madrasah, even though madrasah has just been known since the early $20^{\text {th }}$ century. The first madrasah established was Madrasah al-Sibyan. This madrasah was established in 1905 with the focus of education on memorizing al-Qur'an. At the same time, the first modern madrasah was madrasah al-Iqbal, established in 1908 by Islam reformists. In the next period, the establishment of madrasah was supported by Muslim scholars in order to develop Islamiyah preach through education. At its height, Singapore built 26 madrasas in 1966.

Moreover, after tracing the Islamic education theory, the writer argues that pesantren becomes the most central educational model in resisting phenomena of religious radicalism. Inclusive pesantren becomes antithesis the failure of education in teaching values of tolerance and friendliness. Through its epistemology, pesantren contributes intellectual advancement of inclusive and tolerant Islamic education. Through primary contextualization sources of religion, contemporary scholarly, and cultural preservation, the efficacy of religious education can enhance. The theoretical basis will be tested in implementing Islamic education in Indonesia and Singapore. Identification and polarization of the Islamic education model in both countries become a role model of the implementation of an ideal education.

\section{Religious Education Vis a Vis Religious Radicalism}

Religious Education and Radicalism are two different things and have a distinct vision and system orientation or movement. Religious education has the vision to build a young generation with noble characters, democratic, and intelligent. The orientation of religious education is to 
create a pious person and fear of God, to build a civilization and humanity, and to create prophetic students. That is the conformity between words and deeds (tabligh, shidiq, fathanah, and amanah).

Whilst, religious radicalism is a symptom of the emergence of extremism and violence that uses religion for a socio-political change. The vision and orientation of the religious radicalism movement are to create chaos, restlessness, and terror against a community. Thus, it creates distrust between society and the government and causes suspicion between one group and other groups (social distrust).

In fact, there has been a conceptual and epistemic dynamics of religious radicalism in historical reality. Moreover, when radicalism is attached to other terminologies such as fundamentalism, jihad, extremism, and terrorism. So, to anticipate the confusion of such definitions, Abdul Mukti Rouf (2007) suggests that it is necessary to carry out epistemic and socio-historical exploration of radicalism movements in Indonesia. Padri War Movement (1830-1837), Aceh War (1873-1942), and War of Prince Diponegoro (1825-1830) are very different from religious radicalism used by post-New Order groups such as FPI and the Amrozi movement, and others. Radicalism during those wars, religion was used to inflame the spirit of jihad for a positive purpose against any kind of colonialism. At the same time, religious radicalism that emerged later was used for practical politics and even destructive, instilling group sentiment, hostility, and conflict.

Religious radicalism is a serious threat to NKRI (Unitary State of the Republic of Indonesia). Hikam (2018) said that radicalism is troublesome, tearing apart a sense of nationalism and threatening the pillars of life of the nation and state. Because religion is pulled out to momentary political interests and justifies any means, a religion that should build cohesion and social solidarity, mutual respect, and tolerance is used by irresponsible people for dirty, hard, and rigid political power.

Why does radicalism become a threat to the Republic of Indonesia? It is because Indonesian society horizontally shows the fact of pluralism, 
which consists of various ethnic groups, religions, customs or traditions, and differences in other regional elements. A country that has plural societies such as Indonesia is most vulnerable to SARA (tribe, religion, race, and group) conflicts. The slight difference in views that occurs among communities in a region often triggers divisions, disputes, clashes, and even conflicts between them. We could not deny that the number of violence in the name of religion occurred and actually began since the Reformation Era applied in all aspects and has been increasing in some areas lately. Such a condition was not found in the New Order Era, because at that time, the conflict was successfully suppressed in various ways. Even though it later caused explosions in the present. To name a few are mosque burning during Eid al-Fitr prayer in Tolikara, Papua (2015), church burning by the masses, and causing one to die in Aceh Singkil (2015), attacking GAFATAR members who settled in the West Kalimantan Province (2016). There have also been a number of religious intolerance movements in some regions and have created a stigma radical Islam and far from the Islamic values of rahmatan lil-'alamin.

Radicalism has become a serious threat to the diversity and unity of the NKRI. Even with the involvement of women and children in violent actions and suicide bombings lately, it has become a concern of all parties. This reality needs to be addressed comprehensively by the entire components of the community. The government needs to synergize and embrace all community groups/religious leaders in preventing the infiltration of terrorist networks. The government needs to empower women to participate in terrorism deterrence. Women also need to be involved in educational programs, dialogues, and seminars as an effort to foster awareness of the danger of radicalism for families and society.

To find a way out of the roots of religious radicalism, it must be carried out systemically and involve all components of society. The radicalism settlement needs an extraordinary strategy, including revitalizing multiculturalism-based religious education. Education needs to be reconsidered, although it needs a long process. But education is very 
effective in realizing an idealized society. Including education needs to be reconstructed to strengthen the plurality and diversity of society. Education needs to instill an understanding to the students that plurality is a social and cultural capital with high value and serves as the nation's adhesive potential. In addition, education needs to build a democratic culture by developing a view of openness, dialogue, mutual respect, and promoting the values of universal humanism in society. Community diversity needs to be managed properly. If not, it can be a threat of disparity and lead to conflict.

With the spread of the virus of radicalism and the emergence of intolerance attitudes in society, it is important to give awareness to parents, especially the mother, regarding the urgency to participate in giving the right understanding and values existing in social life. As a woman, a mother is usually very close to children. Thus, factors such as encouragement, modeling, and imitation greatly affect children's development. In addition, a mother needs to instill an attitude of harmony and tolerance within the children to be able to respect the religious diversity and culture of the community. In the Indonesian context, children need to be encouraged to accept Pancasila as Philosophisce Grondlang (the philosophical foundation of the state) and as a philosophical consensus from the noble agreement of the founding fathers that come from various groups and differences.

Not less important, religious education also needs to revitalize its education system. At least there are two ways, first provide opportunities for the development of the students in all aspects like physical, emotional, social through an interactive approach. Second, the learning process must be considered as an interactive profession where the teachers facilitate a learning environment that enables children to learn active interactions in a pluralistic society.

If religious education provides an understanding of the importance of each community that has religious differences, faith, and culture, to welcome, respect, love, and help one another, such education will be very 
effective to fuse the boundaries of primordialism and fanaticism which have been the root of conflict, violence, hatred, and suspicion, towards true brotherhood and friendship.

\section{Islamic Education's Response to Radicalism}

Terrorism caused by religious radicalism is an extraordinary crime that threatens the existence and sovereignty of a nation. It is also endangering the world security and peace. In response to this reality, Indonesia and Singapore are quite serious in tackling the development of radicalism and terrorism, like other nations who have declared war against them. The two countries have made various efforts, such as through law enforcement and collaboration with other countries in tackling radical ideologies, violent acts, and terrors. They have also involved financial service providers and police officers, and increased international cooperation to detect funds used (or allegedly used) in terrorism activities (Munip, 2012, p. 158) (although the deradicalization programs initiated by the Indonesian government have been considered a role model for other countries, including Singapore.

As explained by the Head of the National Agency for Counterterrorism (BNPT), there are two types of the approach used by Indonesia concerning terrorism, namely (1) soft approach (preventive approach) through deradicalization and counter-radicalization and (2) hard approach through law enforcement by still considering human rights protection (Pinardi, 2018). Singapore itself gives no mercy in combating the terrorists. This fact has been proven by the arrest of the key actors and the suspected terrorists from among civilians. More specifically, the country uses three strategies called to prevent, protect, and respond and invites active participation and cooperation of the government and private agencies to manage the risks of terrorism (Nugraha, 2018).

Equally important are facts presented by Islamic education in both countries in responding to the issue of terrorism and in promoting efforts of counter-radicalism. The role of religious institutions and educations, 
however, must be in accordance with their proportions (Zuhdi, 2017: 199), with special concern to the mainstream Islamic groups who feel very disadvantaged with violent acts committed by the terrorists hijacking the name of Islam. Indeed, the radicalism phenomenon has led to fears and negative stereotypes of Islam, i.e., Islamophobia. As described above, the counter-radicalism and deradicalization programs through education and culture have been carried out by many traditional and modern pesantren in Indonesia and many madrassas in Singapore.

Although there are various types of strategies, methods, and curricula applied by the Islamic education in Indonesia and Singapore in counterradicalism, the mainstream Islamic groups share a common view about the transnational movements that use the name of Islam but are very deviant from the fundamental teachings of the religion. According to mainstream groups, Islam developed and taught in both countries has universal values, e.g., tolerant, democratic, and pluralist. Such an Islam is different from the one exhibited by the terrorists that display rigid religious teachings and tends to promote a single model of Islam as in the Prophet era. This model of Islam, according to experts, in turn, will lead to fanaticism and give birth to exclusive and intolerant attitudes, even radicalism (Afdlal \& Irewat, 2005, p. 8). Unfortunately, those who are included in this radical group dare to legitimize their violent acts by using the sacred texts of religion. They monopolize the truth claim, think dogmatically, reject differences, and use rude expressions, such as betrayal, kufr, infidel, and so on. Their perspectives of Islam, according to Abd A'la (2002, p. 17), are very different from the wider community, including the government. Their main agenda is to replace the national ideology with an ideology originating from the Shari'a.

The counter-radicalism movement developed through Islamic education in Indonesia and Singapore provide religious instructions that place Islam as rahmatan lil 'alamin (as a mercy to the world) and peaceful religion. Moreover, pesantren in Indonesia and Islamic education in Singapore are essentially tolerant and inclusive institutions. They practice 
Islam, not in the extreme, but moderate way as explained by a popular saying in Islam, namely: khairu l-umur awsathu-ha (the best of all things to do is the moderate way). In this sense, Islamic education is used as a place for internalizing and implementing values, ethics, and mutual respect among different religions, cultures, languages, ways of life, customs, and habits. The methods and curriculum construction applied are more oriented towards strengthening religion, nationalism, and democracy.

\section{Transmission of Cosmopolitanism in the Practice of Islamic Education}

The emergence of terrorism caused by religious radicalism is another variant of extremism movement that can be a serious threat to the governments of Singapore and Indonesia. Yet, terrorism in Singapore is relatively rare as compared to Indonesia. In Indonesia, terrorism action often occurs on behalf of religion, for instance, by applying the concept of offensive jihad through suicide bombing, terror, and violence. Such a concept of jihad is wrong and not in accordance with the true meaning of jihad.

Based on the fact about the proliferation of radical teachings, the governments of Indonesia and Singapore have carried out various strategic efforts in the context of counter-radicalism and deradicalization. There are lots of things that have been carried out by the Indonesian and Singapore governments, both in the regulatory aspect and political will, with very serious sanctions to those who commit terrorism actions. In addition to increasing international cooperation in countering terrorism, the Singapore and Indonesian governments also collaborate with various institutions to participate in tackling and minimizing the teachings of radicalism that have led to terrorism.

Not less important is involving Islamic educational institutions, both madrasa, and pesantren. Interestingly, based on the results of research in several Islamic educations in Indonesia, especially in the salaf and modern pesantren and in several Sunni schools in Singapore as described above, there are some differences between the Islamic education system in 
Singapore and Indonesia, especially in the matter of adequate infrastructure, professional education management, modern curriculum, and big salaries. In Indonesia, it is varied depending on the system of education. For instance, the pesantren with the Salaf model is usually simple, applying simple management, using the traditional curriculum, and giving little salary while modern pesantren are usually managed professionally with a modern and integrated curriculum.

But interestingly, despite the differences between the Islamic education system in Indonesia and Singapore, there are still the same patterns and movements when responding to the emergence of religious radicalism that is very frightening, rejecting development, and threatening pluralism. Based on the results of comparative observations and research in a number of pesantren and madrasa in both countries, it can be said that the philosophy and practice of Islamic education applied in both countries emphasizes an educational system that transmits values that are often called as cosmopolitanism. This view roots in modern human thinking and is not separated from the traditions of the local community or not separated from the environment. According to Wattimena (2018), cosmopolitanism is a way out of extreme universalism that often causes hegemony in the name of diversity as well as avoids narrow and radical particularism attitudes.

The counter-radicalism design that has been carried out by Islamic educational institutions in both countries does not fight radicalism with violence. However, it is more concerned with constructing the goals and curriculum of Islamic education, which further promotes peaceful Islam, strengthens tolerance, and democratic education, and respects pluralism. Borrowing the language of Ustadz Razak in Republika (2009), the head of the Singapore Madrasa "Madrasa has included Islamic needs as beliefs that must live and interact in the midst of other communities and religions."

At the same time, it is transmitting the values that are often called by Gus Dur with Islamic universalism and cosmopolitanism of civilization. These values are reflected in the teachings of Islam that have a concern on the elements of humanity, which are balanced with the wisdom that arises 
from the openness of Islamic civilization itself (Madjid, 1994, pp. 3-5). The transmission of Islamic cosmopolitanism through Islamic education means trying to create a young generation of Islam that is more capable of displaying enormous concern of the main elements of humanity, uphold the equality before the law and constitution, protect the citizens from every kind of injustice and arbitrariness, and safeguard the rights of the weak, and guarantee the safety of their respective religious beliefs. Pesantren and madrasa in Indonesia and Singapore have been designed in such a way as to create students who are intelligent, open-minded, competitive, and have a religious understanding of Islam that is friendly, peaceful, tolerant, respectful, and not radical, far from the doctrine of terrorism, not accusing infidel to others, or even justifying suicide bombings in the name of jihad.

While the approach adopted by mainstream Islamic education in both Indonesia and Singapore as the characters of the cosmopolitan generation is to prioritize dialogue, flowing communication, and critical thinking to solve the problems encountered by students every day, while the model and approach of the traditional pesantren in Indonesia to generate critical thinking among students and to contribute to problem-solving is through bahsul masail (scientific colloquy) strategy. At the same time, modern pesantren in Indonesia and madrasa in Singapore have implemented active learning. In short, the existence of pesantren and madrasa in Singapore and Indonesia as the agents of change for society in globalization discourse has become mediation to understand the problems that arise in society. At the same time, transforming the lives of people in both countries towards civil society, being able to respect each other, uphold human values and nationality - as the basis of Islamic cosmopolitanism.

\section{Islamic Education in Indonesia and Singapore: Building a Democratic Society}

As a matter of fact, Indonesia and Singapore have a pluralistic society in terms of ethnic groups, religions, customs or traditions, and other regional elements. This plurality is a social and cultural capital that is 
highly valued and functions as the adhesive potential of the nation that needs to be managed by all elements, both government and society. In line with this notion, there is an urgent need to build a democratic culture by promoting openness, dialogue, mutual respect, and values of humanism in society. If not managed properly, such potential can be a threat leading to horizontal conflicts.

Building a democratic culture in society is not an easy task, like reversing palms of hands, nor is it taken for granted. Rather, democratic values must be fought for, seeded, nurtured, and raised through systematic, planned, and directed efforts. The democratic values, according to Azra (2002), cannot be inherited. They need to be studied and practiced slowly but continuously until they become a habit that helps encourage awareness for the community about the importance of democratic values in everyday life.

If democratic attitudes are well embedded in society, all problems faced by a nation can be solved through deliberation without conflict or violence. Countries with pluralistic societies like Indonesia and Singapore are indeed most vulnerable to conflicts based on ethnicity, religion, race, and inter-group relations. No matter how small the differences of opinion that occur between groups of people in a region, they may trigger disputes, clashes, and even conflicts. In Indonesia, a number of violence in the name of religion often occur, especially after the Reform Period, and have been increasing in many regions. This condition was different compared to that in the New Order era. At that time, the conflicts were successfully suppressed in various ways, although they later culminated and caused explosions in the current era. All of this must be resolved immediately, including through religious perspectives. In this context, religion needs to be viewed with comparative approaches through dialogues, in order to promote mutual understanding and cooperation, as well as minimize suspicion and religious conflicts.

Of course, religious dialogue requires an objective-critical paradigm because religion can be seen as a truth rather than an identity. When 
religion, referring to Abdul Karim Soroush's statement, is seen only as an identity, it can provoke hostile attitudes with other parties or religions. For example, although Muslims think of their identity and civilization as the right ones, they should not impose them for political purposes, the socalled political Islam, or the politicized religion (Zainuddin, 2016, p. 5). Indeed, religious dialogue should function as an integrative factor, as stated by a contemporary Islamic thinker Al-Jabiri in his Democracy, Human Rights and Law in Islamic Thought (2008). With this framework, the religious dialogue is not looking for opponents, nor is it trying to defeat other parties. Rather, together with all religions, it wants to give an answer or solution to social problems. Hence, to arrive at the level of such a mature and dialogical religious community, it is necessary to optimize the roles of Islamic education in order to prepare a democratic society as expected.

\section{Instructional Curriculum, Strategy and Method}

The religious community in multicultural society needs to reorient their education and teaching practices by avoiding the mere textualnormative approach. Instructional activities should not focus only on the transfer of information, but they must be able to encourage students to have moral intelligence and democratic values. The curriculum of Islamic education must be conceived in an inclusive frame that promotes tolerance and civic values in learning activities. The materials should stimulate multicultural understanding and awareness in daily life. They can be based on historical facts and realities in Islam, such as the practices of social interaction applied by the Prophet Muhammad when building the community of Medina. From this historical fact, recognition and appreciation of the pluralism and tolerance values can be expected. In addition to the normative texts, students are also trained to observe concrete cases in society, so that they may realize that they live in a situation where differences do exist. 
Here, Islamic education is always tried to be gradually freed from primordial barriers by emphasizing Islamic education based on Multiculturalism and togetherness. In Abdurrahman Wahid's analysis, education needs to promote a pluralistic community since this concept is considered able to support peaceful coexistence in an era in which misunderstanding between social groups is still obvious and can lead to disintegration. Besides, appreciation for plurality indicates an awareness to get to know each other and build sincere dialogue. With this in mind, each person in a group may give and receive from one another (Wahid, 1992).

The learning method developed is no longer indoctrination, but it should be set in a dialogical atmosphere. In this context, students are invited to interact with pluralistic reality found both inside and outside the classroom; they are invited to explore the values of humanity and traditionalize the building togetherness with others. They should be occasionally invited to join a dialogue with religious leaders or people from other religions, so that they may feel direct experience to blend and get to know each other. Such a way can foster appreciation and tolerance towards other religions through discussion, dialogue, and exchange of experiences about various problems faced by other groups (Asroni, 2011, p. 126). All these efforts are meant to foster sensitivity, a sense of solidarity, and appreciation for other groups.

In case the students have been attached to radicalism, the teacher must intensify communication and approaches to them in a persuasive manner, and provide an understanding of the concept of Islam Rahmatan li l-Amin 'Alamin. He or she also needs to invite them to discussion intensively, from heart to heart, concerning the dangers of radicalism for students, society, and the state.

As an effort to counter radicalism, the teaching and learning process in madrassas and boarding schools must be designed to enable productive interaction between teachers and students. Instructional activities should not be dominated by the teacher and make the students less active. They should participate, not merely listen. This learning approach should be 
designed into a two-way interaction. That is, the teacher does not focus only on the cognitive development of the students, but also on their affective and psychomotor aspects (Jeffrey \& Woods, 1998, p. 2). Such an approach will not give birth to a rigid, exclusive, and militant perspective of religion. It is also necessary to reformat forms of education integrated with the wider society by accommodating the dynamics of social realities and requiring flexibility in thinking in order to create social and national integrity. Moreover, an integral model of religious education that emphasizes religious normativity and historicity, as experts believe, will give birth to a civilized society, an ideal society that is always based on moral principles upholds the values of civilization, and guarantees a balance between individual freedom and social and national stability.

\section{Reconstructing the Goals of Islamic Education for Humanity}

Education is a determinant factor of the future of a nation because of its ability to enlighten future generations. An unclear vision of education will have an impact on the welfare and progress of the nation. Therefore, Islamic education must formulate a clear goal and vision compatible with the nation's problems. Therefore, the Islamic education system should not be static; rather, it must be dynamic and responsive to any change. The changes that occur in the Islamic education system must also be accompanied and based on a solid vision in responding to the challenges of the times. Relevant to this issue, Islamic education must be able to answer the demands for the welfare of society and the progress of the nation. There are at least four goals which become the idealism of Islamic education, according to Haryatmoko (2008, p. 67), namely: (1) the acquisition of knowledge and skills (competency) as it is related to the market demand, (2) the humanistic orientation, (3) the responsiveness to social, economic, and justice challenges, and (4) the progress of science.

Out of the four educational goals, the fourth point, which is oriented towards humanity, becomes an important point in the education process. This point shows that Islamic education must uphold the students' rights in obtaining knowledge and information. Besides, Islamic education must 
also strengthen the spirit of nationalism in students. Looking at the historical record, Islam and Nationalism have colored the development of the Islamic education system in Indonesia. Since Islam came to Indonesia to the Dutch colonial period until now, Islamic education has tried to realize Islamic values in social lives, including Islamic nationalism. It has also created a civil society and democracy (Djamas, 2009, pp. 1-2).

Moreover, democracy has always been a universal humanitarian concern because it is the pillar of civilization. There is no single group or nation that rejects democracy as far as it is defined as an effort to realize people's sovereignty. In Indonesia, democracy continues to roll along with political dynamics. According to Nurcholish Madjid (1998, p. 19), we have democracy as an ideology not only because it brings values that are justified and supported by the spirit of Islamic teachings, but also because it supports an open and fair political play.

In reality, there is a meeting point between nationalism, democracy, and Islamic education. This meeting point can be traced from the contributions of the Islamic leaders at the beginning of the Republic formation. The history has proven that nationalism, democracy, and Islamic education in this country should not be underestimated as they are the foundation to create quality persons who are ready to live in harmony, peace, and unity with principles of mutual love. Islamic nationalism, according to Purwoko (2001, p. 36), is a determining factor that binds the spirit and loyalty to create the ideals of the country. Besides, the growth of nationalism has given birth to many independent countries throughout the world because it has played its important and positive role in sustaining unity. At this point, it is understandable why the country is able to increase prosperity and improve the quality of education, especially Islamic education.

\section{Rethinking the Islamic Education in Building Ukhuwwab (Brotherhood)}

Considering the role of Islamic education in Indonesia and Singapore in building a democratic society, such a role needs to be continued, 
formulated, and rethought to be more effective and successful. This is very important because Islamic education has been contributing to building the social life of the Indonesian people who are predominantly Muslim to be better, civilized, and dignified. If seen from ideological and sociological perspectives, the Muslim community is not composed of a single and monolithic community. Although the label of Muslim societies is commonly associated with those who embrace Islam and have the same base in religion, i.e., the Qur'an and Hadith, it does not mean that they automatically have uniformity of views in matters of worship, social life, and other religious expressions, more importantly regarding responses to issues of modernity.

Such a diversity of the Muslim community must be properly managed so as to create mutual respect and tolerance for the realization of the ukhuwah community, both inside and outside the Muslim community. At this point, Islamic education functions as social engineering in shaping a democratic, just, and civilized community finds its significance. Islamic education must be able to minimize a rigid perspective and fanaticism, both of which are less friendly and less supportive of the creation of a democratic society. Moreover, in the historical record of humanity, this Muslim society with a conservative attitude often exhibits violent acts and even war.

The concept of democracy in Islamic political discourse is indeed a new phenomenon. Other issues, such as modernity, pluralism, gender, and human rights, have also led to the pros and cons and polarization of the Muslim community up to now. If analyzed thoroughly, the differences of opinion between them still revolve around the problem of the source and origin of the concept of democracy, which actually comes from the Western tradition. Some Muslim societies reject democracy because it is a product of human reason, while Islam is a final religion that is supposed to regulate all the problems based on God's words, i.e., Islam. According to Luthfi Assyaukanie, Muslim groups that reject democracy argue that it 
contradicts the concept of God's sovereignty. For them, democracy puts its sovereignty in human hands (Assyaukanie, 2011, p. 42).

While some other Muslim groups think that democracy is considered a neutral system and is ideal in the present era, for them, it is not against Islam. As a political system, democracy may be more supportive of Islamic teachings than other systems. For this group, democracy and Islam are indeed interconnected. Although democracy is not from the Islamic tradition, it has been applied since $2500 \mathrm{BC}$, when Islamic civilization had not emerged yet. In a historical perspective, the emergence of the concept of democracy, according to Ali \& Surdiasis (2006, pp. 134-135), is inspired by the Greek tradition, which has practiced a system of direct democracy by giving people their rights to make political decisions carried out directly by them. Furthermore, the democratic system grew in Europe at the end of the Middle Ages, which was marked by the birth of Magna Charta in England. Then in the $16^{\text {th }}$ century Europe, a renaissance movement emerged and sought to revive interests in the ancient Greek literature, cultures, and the religious revolution aimed at criticizing the church doctrines.

There are several basic norms of democracy, namely: 1) awareness of pluralism, 2) deliberation, 3) efforts in line with the goals, 4) honesty in agreement, 5) freedom and equality of rights and obligations, and 6) trial and error in democracy (Ubaedillah \& Rozak, 2016). The implementation of all these norms of democracy is believed by many to give birth to modern society, termed as civil society. The image of civil society in a democratic society is characterized by society with polite attitudes, a society with political literacy, and society with participation in political matters to realize common goals (Goldfarb, 1998).

Soemardjan (2000, p. 273) explained that the parameters for the realization of a democratic society are: 1) society with positive freedom and 2) the realization of a balanced political position between citizens and the government. Soemardjan (2000, p. 272) further explained that the characteristics of a democratic state are: 1) political forces formed by society, such as parties, stakeholders, and opposition groups that function 
as instruments for delivering public aspirations to the government, 2) general elections held regularly with a balanced political position between citizens and the government, 3) the government created by the majority while respecting the rights of minority groups, 4) checks and balances between power centers which are reflected in their existence and activities in parliament, and 5) political space and discourse that cannot be intervened by the government.

Islam, in reality, brings the same spirit as aspired by a democratic society. If viewed critically, Islam contains several teachings that are in line with the concept of democracy, such as the deliberation, trust, honesty, solidarity with fellow human beings, equality of positions before the law, protection of the weak and minorities, respect to different beliefs, opinion, culture, and world view (Maftuhin, 2010, p. 305). In short, Islam for prodemocracy groups is considered to be a perfect religion. Although Islam doesn't specifically address democracy, democratic values are in line with Islamic sharia. Religion does not discuss democracy, but it supports a system that brings peace to people.

In addition to those considerations, pro-democracy Muslim groups also showed that democratic systems run by Western countries turned out to be more Islamic than the Islamic monarchy applied by Muslim rulers. That is why it is not surprising that the kyai see the reality of Islamic teachings exactly when they come to Western countries, which are, in fact, secular, such as America, the Netherlands, Germany, and others. Indeed, most people in the West have actually applied the principles taught by Islam, such as humanism, equality, tolerance, justice, freedom, and even issues related to cleanness. Therefore, Islam is a system that justifies and supports the democratic political system as practiced in developed countries (Ubaedillah \& Rozak, 2016, p. 86). The argument saying that democracy will take over God's sovereignty is not right because democracy does not deal with theological but worldly matters.

It is not easy to bring together different views among Muslims, but it does not mean there is no middle way. It is true that religion is something 
that is believed to come from God, especially Islam, which is not made of human thought, while democracy is clearly a product of human thought. However, religion and democracy are interrelated since they are directly related to humans. Religion is a human response to their God, while democracy is a human response to their fellow beings in the context of interaction with each other (Madjid, 1994, p. 189).

Moreover, the roots of democratic thoughts are actually based on humanitarian commitments, which are the fundamental teachings of Islam. Hence, controversy about the concept of democracy should be final. This commitment to human values can be used as a basis for resolving the main challenges of Muslim politics in modern and pluralistic societies, such as in Indonesia. Humanitarian commitment is basically to promote tolerance and have a strong concern for social harmony.

In addition, according to Gus Dur, there are several reasons why Islam can be regarded as a democratic religion. First, Islam is a religion with rules to obey. In this context, Islam applies to everyone regardless of their class and position. Second, Islam has a principle of deliberation, in which each case must be discussed together. Third, Islam is always promoting a view to improving life, since according to Islamic teachings, this worldly life is, in essence, considered a preparation for life in the hereafter (Wahid, 1992, pp. 83-85). Moreover, Islam, in fact, had implemented democratic values since the time of the Prophet before the values of democracy were popularized by the Western thought, especially at the time of the first and second Aqabah. At that time, the Prophet was chosen to be an imam by people from Medina. After the Prophet died, the election system of the Khulafaur Rashidin was carried out by means of deliberation, as can be seen from electoral democracy by tribal representatives and groups.

\section{Conclusion}

Terrorism caused by religious radicalism is a variant of extremism movements which bring a serious threat to the governments of Singapore and Indonesia. Sporadic and changing in nature, this type of crime uses 
the name of religion, and its movements are very neat, sophisticated, and systematic. They do raise fear in society. Hence, it is crucial that all Islamic institutions and communities be vigilant; otherwise, they will be easily influenced and indoctrinated by the movements whose teachings are violent and contrary to the values of religion.

In Indonesia and Singapore, both terrorism and radicalism have been endangering the society and the government. Indeed, radical movements have now dared to penetrate any community and disseminate their teachings openly, although it should be noted that terrorism is relatively rare in Singapore. Unlike in Singapore, terrorism in the name of religion has happened frequently in Indonesia, such as offensive jihad through suicide bombing, direct terrors, and violent acts. This misconception of jihad is not in accordance with the real meaning of jihad.

Considering the widespread radical teachings, the governments of Indonesia and Singapore have carried out various strategic efforts, such as through counter-radicalism and deradicalization. The two countries have also made a political will, issued strict regulations, and strengthened law enforcement in tackling radical ideologies, violent acts, and terrors. They have also increased international cooperation and collaboration to minimize radical teachings leading to terrorism. [w]

\section{References}

Afdlal, \& Irewat, A. (2005). Islam dan Radikalisme di Indonesia. Jakarta: Yayasan Obor Indonesia.

A'la, A. (2002). Melampaui Dialog Agama. Jakarta: Kompas.

Ali, D. J., \& Surdiasis, F. (2006). Demokrasi Indonesia: Visi dan Praktek: Opini Denny JA, Harian Kompas. Jakarta: Pustaka Sinar Harapan.

Arifin, S. (2014). Membendung Arus Radikalisasi di Indonesia. Islamica: Jurnal Studi Keislaman, 8(2), 392-420. https://doi.org/10.15642/ islamica.2014.8.2.392-420

Asroni, A. (2011). Membendung Radikalisme, Merajut Kerukunan Umat Beragama: Sebuah Upaya Rekonstruktif terhadap Pengajaran 
Pendidikan Agama Islam di Perguruan Tinggi Umum. Penamas, XXIV (1).

Assyaukanie, L. (2011). Ideologi Islam dan Utopia: Tiga Model Negara Demokrasi di Indonesia. Jakarta: Freedom Institute.

Azra, A. (2002). Paradigma Baru Pendidikan Nasional: Rekontruksi dan Demokrasi. Jakarta: Kompas.

Bakri, S. (2004). Islam dan Wacana Radikalisme Agama Kontemporer. Jurnal Dinika, 3(1), 1-8.

Djamas, N. (2009). Dinamika Pendidikan Islam di Indonesia Pascakemerdekaan. Jakarta: Rajawali Pers.

Esposito, J. L. (1995). The Islamic Threat: Myth or Reality? Oxford: Oxford University Press.

Goldfarb, J. C. (1998). Civility and Subversion: The Intellectual in Democratic Society. Cambridge: Cambridge University Press.

Haryatmoko. (2008). Menemukan Kembali Kebangsaan dan Kebangsaan. Jakarta: Departemen Komunikasi dan Informatika.

Hikam, M. A. (2018). Pendidikan Multikultural dalam Rangka Memperkuat Kewaspadaan Nasional Menghadapi Ancaman Radikalisme di Indonesia. Global: Jurnal Politik Internasional, 17(1), 1-17. https://doi.org/10.7454/global.v17i1.26

Hilmy, M. (2013). The Politics of Retaliation: The Backlash of Radical Islamists to the Deradicalization Project in Indonesia. Al-Jami'ah: Journal of Islamic Studies, 51(1), 129-158. https://doi.org/ 10.14421/ajis.2013.511.129-158

al-Jabri, M. A. (2008). Democracy, Human Rights, and Law in Islamic Thought. London: IB Tauris.

Jahroni, J. (2004). Gerakan Salafi Radikal di Indonesia. Jakarta: Raja Grafindo Persada.

Jeffrey, B., \& Woods, P. (1998). Testing Teachers: The Effect of School Inspections on Primary Teachers. London: Routledge.

Kosim, M. (2011). Pendidikan Islam di Singapura. Al-Tabrir: Jurnal Pemikiran Islam, 11(2), 433-455. https://doi.org/10.21154/altahrir.v11i2.43

Ma'arif, S. (2016). Pendidikan Inklusif Berbasis Kearifan Lokal. Yogyakarta: Kaukaba Press. 
Machali, I. (2013). Peace Education dan Deradikalisasi Agama. Jurnal Pendidikan Islam, 2(1), 41-64. https://doi.org/10.14421/jpi.2013. 21.41-64

Madjid, N. (1994). Demokratisasi Politik, Budaya dan Ekonomi. Jakarta: Paramadina.

Madrasah Singapura Berkurikulum Moderen. (2009, April 24). Republika Online. Retrieved from https://www.republika.co.id/berita/duniaislam/islam-mancanegara/09/04/24/46161-madrasah-singapuraberkurikulum-moderen

Maftuhin. (2010). Nuansa Studi Islam. Yogyakarta: Teras.

Majid, N., Hidayat, K., \& Gaus AF, A. (1998). Passsing Over: Melintas Batas Agama. Jakarta: Gramedia.

Misrawi, Z. (2013). Kesadaran Multikultural dan Deradikalisasi Pendidikan Islam: Pengalaman Bhinneka Tunggal Ika dan Qabul alAkhar. Jurnal Pendidikan Islam, 2(1), 197-215. https://doi.org/ 10.14421/jpi.2013.21.197-215

Munip, A. (2012). Menangkal Radikalisme Agama di Sekolah. Jurnal Pendidikan Islam, 1(2), 159-181. https://doi.org/10.14421/jpi. 2012.12.159-181

Noor, F. A., van Bruinessen, M., \& Sikand, Y. (2008). The Madrasa in Asia: Political Activism and Transnational Linkages. Amsterdam: Amsterdam University Press.

Nugraha, AA. B. S. W. (2018). Singapura dan Permasalahan Terorisme. Research Report. Program Studi Hubungan Internasional Fakultas Ilmu Sosial dan Ilmu Politik Universitas Udayana Bali.

Pinardi, S. (2018, May 4). Di Singapura, BNPT Paparkan Strategi Penanggulangan Teroris. Kompas.

Purwoko, D. (2001). Negara Islam? Percikan Pemikiran: H. Agus Salim, KH Mas Mansyur, KH Hasyim Asy'ari, dan Mohammad Natsir. Depok: Permata Artistika Kreasi.

Rijal, S. (2010). Radikalisme Islam Klasik dan Kontemporer: Membanding Khawarij dan Hizbut Tahrir. Al-Fikr, 14(2), 214231.

Rokhmad, A. (2012). Radikalisme Islam dan Upaya Deradikalisasi Paham Radikal. Walisongo: Jurnal Penelitian Sosial Keagamaan, 20(1), 79_ 114. https://doi.org/10.21580/ws.20.1.185 
Ro'uf, A. M. (2007). Mengurai Radikalisme Agama di Indonesia Pasca Orde Baru. Ulumuna, 11(1), 157-176. https://doi.org/10.20414/ ujis.v11i1.425

Soemardjan, S. (2000). Menuju Tata Indonesia Baru. Jakarta: Gramedia Pustaka Utama.

Ubaedillah, A., \& Rozak, A. (2016). Pancasila, Demokrasi, HAM dan Masyarakat Madani. Jakarta: Prenadamedia.

Umam, S. (2006). Radical Muslims in Indonesia: The Case of Ja'far Umar Thalib and the Laskar Jihad. Exploration in Southeast Asian Studies, 6(1), 1-26.

Wahid, A. (1992, November 20). Pluralitas Agama dan Masa Depan Indonesia. Paper presented in the seminar of the religion and society. UKSW Salatiga.

Wattimena, R. AA. (2018). Kosmopolitanisme Sebagai Jalan Keluar atas Tegangan Abadi antara Neokolonialisme, Radikalisme Agama, dan Multikulturalisme. Jurnal Ledalero, 17(1), 119-132. http://dx.doi.org/10.31385/jl.v17i1.59.119-132

Zainuddin, M. (2016). Islam Moderat: Konsepsi, Interpretasi, dan Aksi. Malang: UIN Maliki Press. 